\title{
STEAP1 is overexpressed in cancers: a promising therapeutic target
}

\author{
Jerome Moreaux ${ }^{\star \ddagger}$, Alboukadel Kassambara ${ }^{\ddagger}$, Dirk Hose ${ }^{\circ}$ and Bernard Klein ${ }^{\star \ddagger \dagger}$
}

${ }^{*}$ CHU Montpellier, Institute of Research in Biotherapy, Montpellier, FRANCE;

‡ INSERM, U1040, Montpellier, F-34197 France;

† Université MONTPELLIER1, UFR Médecine, Montpellier, France;

○ Medizinische Klinik und Poliklinik V, Universitätsklinikum Heidelberg, Heidelberg, Germany

Corresponding author: Jerome MOREAUX

INSERM-University Montpellier I U1040

Institute of Research in Biotherapy CHU Montpellier, Av Augustin Fliche

34285 Montpellier cdex, FRANCE

Tel 33-(0)467337888

Fax 33-(0)467337905

Mail: jerome.moreaux@inserm.fr

http://irb.chu-montpellier.fr/index.htm

Abstract word count: 134 words

Text character count: 2246 words 


\begin{abstract}
The six-transmembrane epithelial antigen of prostate (STEAP) protein was identified in advanced prostate cancer and is up-regulated in multiple cancer cell lines, including prostate, bladder, colon, ovarian, and Ewing sarcoma. STEAP1 was described as a suitable antigen for T-cell-based or antibody-based immunotherapy.

We have investigated the expression of STEAP1 in 40 human tumor types - brain, epithelial, lymphoid - and in their normal tissue counterparts using publicly available gene expression data, including the Oncomine Cancer Microarray database. STEAP1 was found significantly overexpressed in 11 cancers. In addition, high STEAP1 expression was associated with poor overall survival in colorectal cancer, diffuse large B cell lymphoma, acute myeloid leukemia and multiple myeloma.
\end{abstract}

Taken together, these data suggest that STEAP1 is a potential therapeutic target for Tcell based immunotherapy or antibody therapy in a large panel of cancers. 


\section{Introduction}

The six-transmembrane epithelial antigen of prostate (STEAP) protein was identified in advanced prostate cancer[1]. STEAP1 is highly expressed in human prostate cancer and is up-regulated in various cancers, including lung, bladder, colon, ovarian, and Ewing cancers [1,2,3]. Immunohistochemical analysis of clinical specimens demonstrates significant STEAP1 expression at the cell-cell junctions of the secretory epithelium of prostate and prostate cancer cells[1]. Little to no staining was detected at the plasma membranes of normal non-prostate human tissues, except for bladder tissue, which expressed low levels of STEAP1 at the cell membrane. Its cell-surface localization, together with its six-transmembrane topology, suggests STEAP1 may function as a channel/transporter protein in cell-cell junctions[1]. Given its increased expression in cancer tissues, STEAP1 could be a promising target for T-cell based or antibody immunotherapy. In prostate cancers, STEAP1-specific cytotoxic T lymphocytes (CTLs) were found to inhibit the growth of transplantable prostate tumor cells in murine models[2,4,5]. An immunization with recombinant DNA or modified vaccinia virus Ankara vector delivering STEAP1 antigen inhibited prostate cancer progression in a murine subcutaneous syngeneic tumor model[6]. Targeting STEAP1 appeared also useful for Tcell based immunotherapy in renal and bladder cancers[7]. Finally, STEAP1 was also described as an attractive target for antibody therapy in multiple solid tumors including prostate, renal and bladder cancers[3].

In this report, we have investigated the expression of STEAP1 gene in 40 human tumor types - brain, epithelial, lymphoid - as well as in their normal tissue counterparts using publicly available gene expression data, including the Oncomine Cancer Microarray 
database. 


\section{Materials and Methods}

\section{Databases and gene expression data}

STEAP1 gene expression in normal or malignant human tissues or cell lines was obtained from the Oncomine Cancer Microarray database (http://www.oncomine.org)[8], Amazonia database (http:// amazonia.montp.inserm.fr/)[9], or ITTACA database (Integrated Tumor Transcriptome Array and Clinical data Analysis, http://bioinfoout.curie.fr/ittaca/)[10]. Comparison of STEAP1 expression between samples was performed only when gene expression data were from a same study, using the same methodology. Gene expression profiling (GEP) data are either two channel ratio data (from cDNA microarrays) or single channel intensity data (from Affymetrix microarrays). All data were log transformed, median centered per array, and the standard deviation was normalized to one per array[11].

MMCs were purified from 206 patients with newly-diagnosed MM after written informed consent was given at the University hospitals of Heidelberg (Germany) or Montpellier (France). The study was approved by the ethics boards of Heidelberg and Montpellier Universities. After Ficoll-density gradient centrifugation, plasma cells were purified using anti-CD138 MACS microbeads (Miltenyi Biotech, Bergisch Gladbach, Germany). Microarray experiments were performed in DNA microarray platform of the Institute of Research in Biotherapy at the Montpellier University Hospital (France) (http://irb.montp.inserm.fr/en/index.php?page=Plateau\&ldEquipe=6). The .CEL files and MAS5 files have been deposited in the ArrayExpress public database (E-MTAB-372). We also used Affymetrix data of a cohort of 345 purified MMC from previously untreated MM patients from the University of Arkansas for Medical Sciences (UAMS, Little Rock, 
AR). These data are publicly available via the online Gene Expression Omnibus (Gene Expression Profile of Multiple Myeloma, accession number GSE2658. http://www.ncbi.nlm.nih.gov/geo/). We also used Affymetrix data of a cohort of patients with colorectal carcinoma $(\mathrm{N}=177)$ (accession number GSE17538. http://www.ncbi.nlm.nih.gov/geo/) with diffuse large B cell lymphoma $(N=414)$ (accession number GSE10846. http://www.ncbi.nlm.nih.gov/geo/) and a cohort of patients with acute myeloid leukaemia $(\mathrm{N}=79)$ (accession number GSE12417. http://www.ncbi.nlm.nih.gov/geo/). Affymetrix gene expression profiles of 917 cancer cell lines was also investigated for STEAP1 expression (accession number GSE36133). Patient cohorts were described in supplementary appendix 1.

\section{Statistical analysis}

Statistical comparisons were done with student t-test. Gene expression data of MM patients were normalized with the MAS5 algorithm and analyzed with our bioinformatics platforms: RAGE (http://rage.montp.inserm.fr/)[12] and Amazonia (http://amazonia.montp.inserm.fr/)[9]. The prognostic value of STEAP1 gene expression signal was determined using the MaxStat $\mathrm{R}$ function in $\mathrm{R}$ software (http://www.rproject.org). The statistical significance of differences in overall survival between groups of patients was calculated by the log-rank test. Multivariate analysis was performed using the Cox proportional hazards model. Survival curves were plotted using the Kaplan-Meier method. All these analyses have been done with R.2.10.1 (http://www.rproject.org/) and bioconductor version 2.5 .

Western blot analysis 
Cells were lysed in $10 \mathrm{mM}$ Tris- $\mathrm{HCl}(\mathrm{pH} 7.05), 50 \mathrm{mM} \mathrm{NaCl}, 50 \mathrm{mM} \mathrm{NaF}, 30 \mathrm{mM}$ sodium pyrophosphate (NaPPi), 1\% triton X-100, $5 \mu \mathrm{M} \mathrm{ZnCl} 2,100 \mu \mathrm{M} \mathrm{Na}{ }_{3} V O 4,1 \mathrm{mM}$ DTT, 20 mM $\beta$-glycerophosphate, $20 \mathrm{mM}$ p-nitrophenolphosphate (PNPP), $20 \mu \mathrm{g} / \mathrm{ml}$ aprotinin, $2.5 \mu \mathrm{g} / \mathrm{ml}$ leupeptin, $0.5 \mathrm{mM}$ PMSF, $0.5 \mathrm{mM}$ benzamidine, $5 \mu \mathrm{g} / \mathrm{ml}$ pepstatin, and $50 \mathrm{nM}$ okadaic acid. Lysates were resolved on $12 \%$ sodium dodecyl sulfate-polyacrylamide by gel electrophoresis (SDS-PAGE) and transferred to a nitrocellulose membrane (Schleicher and Schuell, Kassel, Germany). Membranes were blocked for 2 hours at room temperature in $140 \mathrm{mM} \mathrm{NaCl}, 3 \mathrm{mM} \mathrm{KCl}, 25 \mathrm{mM}$ Tris- $\mathrm{HCl}(\mathrm{pH} 7.4), 0.1 \%$ Tween 20 (TBS-T), 5\% non-fat milk and human $\mathrm{lg}(1 \mathrm{mg} / \mathrm{ml})$, and then immunoblotted with a mouse anti-STEAP1 mAb (Sigma, St Louis, MO, clone 4F6-1F3). As a control for protein loading, we used a mouse monoclonal anti- $\beta$-actin antibody (Sigma, St Louis, MO). The primary antibodies were visualized with goat anti-mouse (Bio-Rad, Hercules, CA) peroxidase-conjugated antibody by an enhanced chemiluminescence detection system. Blots were quantified by densitometry using acquisition into Adobe Photo Shop (Adobe Systems, San Jose, CA), and analyzing with the NIH Image J software (National Institutes of Health, Bethesda, MD, USA).

Immunofluorescence staining

A total of $5 \times 104$ cells were deposited onto poly-L-lysine-coated slides, fixed in $4 \%$ paraformaldehyde and permeabilized with with $0.1 \%$ Triton. Non-specific staining was blocked by incubating the slides in 5\% BSA-PBS, after which the slides were subjected to labeling with the anti-STEAP1 mAb for $1 \mathrm{~h}$ in a moist chamber. Slides were then washed with PBS and incubated for $1 \mathrm{~h}$ with an Alexafluor 488-conjugated rabbit antimouse antibody (Molecular probes, OR, USA) in a dark moist chamber. Slides were 
washed and mounted with Vectashield containing 4'-6-Diamidino-2-phenilindole (DAPI) (Sigma Aldrich, St Louis, MO, USA), and examined under an epifluorescence microscope (Leica Microsystems, Wetzlar, Germany). 


\section{Results and discussion}

STEAP1 expression was investigated in 40 tumor types including 36 solid tumors and 4 hematological malignancies and in the corresponding normal tissues (Table 1 and Figure 1). Overexpression of STEAP1 was found in glioblastoma compared to normal brain $(P=4.5 \mathrm{E}-5)[13]$; in esophageal cancer compared to normal esophagus in two independent studies $(P=4.5 \mathrm{E}-5,7.4 \mathrm{E}-9)[14,15]$; in pancreatic carcinoma compared to normal pancreas in three independent studies $(P=1.6 \mathrm{E}-13,6.1 \mathrm{E}-5, .007)[16,17,18]$; in prostate carcinoma compared to normal prostate in three independent studies $(P=$ 1.8E-6, 2.4E-4, 9.6E-4)[19,20,21]; in head and neck cancer compared to normal counterpart in three independent studies $(P=2.3 \mathrm{E}-18,1.1 \mathrm{E}-5, .001)[22,23,24]$; in lung carcinoma compared to normal lung in six independent studies $(P=1.5 \mathrm{E}-4, P=2.3 \mathrm{E}-4$, $P=3.9 \mathrm{E}-4, \quad P=5.1 \mathrm{E}-16, P=8.8 \mathrm{E}-16, P=4.5 \mathrm{E}-5, P=7.8 \mathrm{E}-5$ and $P=$ $.005)[25,26,27,28,29,30]$. Overexpression of STEAP1 was also found in primary effusion lymphoma compared to normal $\mathrm{B}$ cells $(P=3.1 \mathrm{E}-5)[31]$ and in various leukemia compared to normal bone marrow: T-cell acute lymphoblastic leukemia $(P=5.6 \mathrm{E}-9)[32]$, acute myeloid leukemia $(P=5.6 \mathrm{E}-9)[32]$; B-cell acute lymphoblastic leukemia $(P=8.3 \mathrm{E}-$ 12)[32]; and T-cell prolymphocytic leukemia $(P=5.1 \mathrm{E}-7)[33]$.

Given that STEAP1 was shown to be expressed in prostate cancer metastases[3] and to be associated with invasive behaviour of Ewing tumors[34], an association between STEAP1 expression and tumor progression and patients' survival was investigated. A high STEAP1 expression was significantly associated with a reduced overall survival in patients with colorectal cancer $(n=177 ; P=.02)$, with diffuse large $B$ cell lymphoma $(\mathrm{n}=414 ; P=.008)$, with acute myeloid leukemia $(\mathrm{n}=79 ; P=.0005)$, or with multiple

myeloma $(\mathrm{MM})(\mathrm{n}=206 P=.01$ and $\mathrm{n}=345 ; P=.02)$ (Figure 2). Patients were split into 
two groups using Maxstat $\mathrm{R}$ function[35] according to STEAP1 expression. In patients with colorectal cancer, a maximum difference in overall survival (OS) was obtained splitting patients in a high-risk group of $26 \%$ patients (STEAP1 signal > 1155 (unlogged GEP data)) with a 50 months median OS and a low risk group of $74 \%$ patients (STEAP1 signal $\leq-1155$ ) with 133 months median OS (Figure 2). In patients with DLBCL, a maximum difference in overall survival (OS) was obtained splitting patients in a high-risk group of $67.6 \%$ (STEAP1 signal > 164 (unlogged GEP data)) with a 73 months median OS and a low risk group of $32.4 \%$ patients (STEAP1 signal $\leq 164$ ) with not reached median OS (Figure 2). In patients with cytogenetically normal AML, a maximum difference in overall survival (OS) was obtained splitting patients in a high-risk group of $10.1 \%$ (STEAP1 signal > 6.07 (log transformed GEP data)) with a 4 months median OS and a low risk group of $89.9 \%$ patients (STEAP1 signal $\leq 6.07$ ) with 20 months median OS (Figure 2). In patients with MM, a maximum difference in overall survival (OS) was obtained splitting patients in a high-risk group of $31 \%$ with a 74 and 67 months median OS respectively in two independent cohorts of patients and a low risk group of $69 \%$ patients with not reached median OS (Figure 2). Furthermore, STEAP1 is significantly overexpressed in malignant plasma cells compared to normal bone marrow plasma cells and in tumor cells of patients with AML compared to normal hematopoietic stem cells (Supplementary Figure 1). In MM, seven molecular groups of tumor cells have been identified in previously-untreated patients [36], and STEAP1 was significantly overexpressed in the proliferation group and in the groups associated with Cyclin D1 or MMSET translocations (Figure 3), two of them (proliferation and MMSET) being associated with poor survival in MM[36]. Using Cox univariate analysis in colorectal cancer patient cohort, AJCC staging, colorectal cancer grading and STEAP1 expression 
had prognostic value. Comparing these prognostic factors two by two, STEAP1 expression remained significant compared to AJCC staging, and colorectal cancer grading (Supplementary Table S1). When these parameters were tested together, STEAP1 expression and AJCC staging kept prognostic value. In MM patient cohorts, UAMS-HRS, IFM-score and GPI (Growth proliferation index) had prognostic value as well as $t(4 ; 14)$, del17p, $\beta 2 \mathrm{~m}$ and ISS (Supplementary Table S2). Comparing these prognostic factors two by two, STEAP1 expression remained significant compared to $\beta 2 \mathrm{~m}$, ISS, IFM-score and GPI (Supplementary Table S2). When these parameters were tested together, only $\beta 2 \mathrm{~m}$ and $\mathrm{t}(4 ; 14)$ kept prognostic value in the two cohorts. In cytogenetically normal AML patient cohort, STEAP1, BAALC, ERG, MN1 and EVI1 expression had prognostic value (Supplementary Table S3). Comparing these prognostic factors two by two, STEAP1 expression remained significant compared to $B A A L C, E R G$, and EVI1 expression (Supplementary Table S3). When these parameters were tested together, only STEAP1 and BAALC kept prognostic value. STEAP1 gene expression was also confirmed at protein level in 5 human myeloma cell lines (HMCLs) and purified primary myeloma cells of 5 patients using western blot (Figure 4A\&B). Normalized STEAP1 protein expression was significantly correlated with STEAP1 Affymetrix expression $(r=.96, P=.01)$ (Figure 4A). STEAP1 gene expression was also validated in HMCLs at protein level by immunofluorescence (Figure 4C). STEAP1 was first identified in advanced prostate cancer. Comparing STEAP1 expression in all of these cancer cell lines, we identified a significant overexpression of STEAP1 in acute lymphoblastic T cell leukemia, diffuse large B cell lymphoma, Hodgkin lymphoma, multiple myeloma, oesophagus carcinoma and lung carcinoma cell lines compared to 
prostate cancer cell lines (Supplementary Figure S2). No significant difference of STEAP1 expression was noted between acute myeloid leukemia, acute lymphoblastic B cell leukemia, Burkitt lymphoma, glioma, pancreas carcinoma and pancreatic ductal carcinoma cell lines compared to prostate cancer cell lines (Supplementary Figure S2). Investigating genes correlated with STEAP1 expression among various tumor samples, we identified 1313 genes, 1041 genes and 638 genes significantly correlated with STEAP1 in colon cancer, DLBCL and MM respectively (Supplementary Tables S4, S5 and S6). Crossing the gene lists, 4 genes appeared correlated with STEAP1 expression: dermatan sulfate epimerase (DSE), ubiquitin-conjugating enzyme E2T (UBE2T), atlastin GTPase 3 (ATL3) and CSL-type zinc finger-containing protein 2 (DPH3) (Supplementary Table S7). These genes are not linked with a specific biological pathway (Ingenuity and Reactome analyses).

Taken together, these data demonstrate that STEAP1 could be an interesting target not only in solid tumors but also in haematological malignancies. Recent study described a function of STEAP1 in mediating the transfer of small molecules between adjacent cells in culture, indicating its potential role in tumor cell intercellular communication [3]. Antibodies directed to STEAP1 inhibited STEAP1 induced intercellular communication of prostate cancer cells in a dose-dependent manner. Furthermore, anti STEAP1 antibodies significantly inhibited tumor growth of patient derived prostate and bladder cancer cells in a mouse model[3]. STEAP1 peptides have been recently demonstrated to induce antigen-specific CTLs that were able to recognize and destroy STEAP1-expressing tumor cells in vitro[2,5]. Active immunization against STEAP1 using DNA prime/modified vaccinia virus Ankara boost strategy inhibits 
prostate cancer progression in a murine model[6]. The immunogenicity of STEAP1 has led to the development of anti-STEAP1 antibody-drug conjugates to combine the specificity of anti-STEAP1 antibody to the cytotoxic potency of chemotherapeutic drugs[37].

Using a dye transfer assay, it was shown that STEAP1 expression in connexin deficient prostate cancer cells induces significant dye transport between cells, which is inhibited by specific STEAP1 siRNA. The predicted secondary structure of STEAP1 as a channel protein supports the possibility that STEAP1 acts as a transporter protein to directly transfer the dye between the cells[3]. More recently, Grunewald et al. demonstrated that STEAP1 is important for anchorage-independent colony-formation and invasiveness of Ewing tumor cells in vitro and for tumorigenicity and metastasis in vivo[34]. In Ewing tumors, STEAP1 expression correlates with increased cellular reactive oxygen species (ROS)-levels, which in turn induce the expression of redox-sensitive and pro-invasive genes. These results sustain previous data that STEAP1 overexpression promotes ROS-mediated hyperproliferation of thyroid epithelial cells[38]. Elevated ROS-levels activate pro-metastatic and pro-proliferative signaling in cancer cells[39,40]. STEAP1 overexpression could promote proliferation, invasiveness, tumorigenicity, and metastasis through ROS-levels upregulation in cancer. A recent study reported the interest of antibody-drug conjugates as promising therapeutic approach combining the STEAP1 antigen targeting specificity of monoclonal antibodies with the cytotoxic potency of chemotherapeutic drugs[37].

\section{Conclusion}


The current analysis emphasizes that STEAP1 could be a good candidate for T-cell based or antibody-based immunotherapy in a large panel of solid and hematological cancers. 


\section{Competing interests}

The author(s) declare that they have no competing interests.

\section{Authors' contributions}

JM designed the study, supported data analysis and wrote the paper.

AK was involved in the study design and supported data analysis.

$\mathrm{DH}$ participated in the design of the study.

BK was involved in the study design and wrote the paper.

All authors read and approved the final manuscript.

\section{Acknowledgements}

This work was supported by grants from ARC (SL220110603450, Paris France), the European Community (FP7- OVERMYR), ANR emergence, FEDER (141786 \& 42667), INCa-Cancéropôle GSO (2012-011) from the Hopp-Foundation, Germany, the University of Heidelberg, Germany, the National Centre for Tumor Diseases, Heidelberg, Germany, the Tumorzentrum Heidelberg/Mannheim, Germany, and the Deutsche Krebshilfe, Bonn, Germany, the Deutsche Forschungsgemeinschaft, Bonn, Germany. We thank the Microarray Core Facility of IRB (http://irb.montp.inserm.fr/en/index.php?page=Plateau\&IdEquipe=6) and the cytometry platform of the Institute of Research in Biotherapy (http://irb.montp.inserm.fr/en/index.php?page=Plateau\&ldEquipe=3, Montpellier Rio Imaging). 


\section{References}

[1] R.S. Hubert, I. Vivanco, E. Chen, S. Rastegar, K. Leong, S.C. Mitchell, R. Madraswala, Y. Zhou, J. Kuo, A.B. Raitano, A. Jakobovits, D.C. Saffran, D.E. Afar, STEAP: a prostate-specific cell-surface antigen highly expressed in human prostate tumors, Proc Natl Acad Sci U S A 96 (1999) 14523-14528.

[2] D.A. Rodeberg, R.A. Nuss, S.F. Elsawa, E. Celis, Recognition of six-transmembrane epithelial antigen of the prostate-expressing tumor cells by peptide antigeninduced cytotoxic T Iymphocytes, Clin Cancer Res 11 (2005) 4545-4552.

[3] P.M. Challita-Eid, K. Morrison, S. Etessami, Z. An, K.J. Morrison, J.J. Perez-Villar, A.B. Raitano, X.C. Jia, J.M. Gudas, S.B. Kanner, A. Jakobovits, Monoclonal antibodies to six-transmembrane epithelial antigen of the prostate-1 inhibit intercellular communication in vitro and growth of human tumor xenografts in vivo, Cancer Res 67 (2007) 5798-5805.

[4] A. Machlenkin, A. Paz, E. Bar Haim, O. Goldberger, E. Finkel, B. Tirosh, I. Volovitz, E. Vadai, G. Lugassy, S. Cytron, F. Lemonnier, E. Tzehoval, L. Eisenbach, Human CTL epitopes prostatic acid phosphatase-3 and six-transmembrane epithelial antigen of prostate- 3 as candidates for prostate cancer immunotherapy, Cancer Res 65 (2005) 6435-6442.

[5] P.M. Alves, O. Faure, S. Graff-Dubois, S. Cornet, I. Bolonakis, D.A. Gross, I. Miconnet, S. Chouaib, K. Fizazi, J.C. Soria, F.A. Lemonnier, K. Kosmatopoulos, STEAP, a prostate tumor antigen, is a target of human CD8+ T cells, Cancer Immunol Immunother 55 (2006) 1515-1523.

[6] M. Krupa, M. Canamero, C.E. Gomez, J.L. Najera, J. Gil, M. Esteban, Immunization with recombinant DNA and modified vaccinia virus Ankara (MVA) vectors delivering PSCA and STEAP1 antigens inhibits prostate cancer progression, Vaccine 29 (2011) 1504-1513.

[7] M. Azumi, H. Kobayashi, N. Aoki, K. Sato, S. Kimura, H. Kakizaki, M. Tateno, Sixtransmembrane epithelial antigen of the prostate as an immunotherapeutic target for renal cell and bladder cancer, J Urol 183 (2010) 2036-2044.

[8] D.R. Rhodes, J. Yu, K. Shanker, N. Deshpande, R. Varambally, D. Ghosh, T. Barrette, A. Pandey, A.M. Chinnaiyan, ONCOMINE: a cancer microarray database and integrated data-mining platform, Neoplasia 6 (2004) 1-6.

[9] S.A. Tanguy Le Carrour, Sylvie Tondeur, Ludovic Lhermitte, Ned Lamb, Thierry Reme, Veronique Pantesco, Samir Hamamah, Bernard Klein, John De Vos, Amazonia!: An Online Resource to Google and Visualize Public Human whole Genome Expression Data, The Open Bioinformatics Journal 4 (2010) 5-10.

[10] A. Elfilali, S. Lair, C. Verbeke, P. La Rosa, F. Radvanyi, E. Barillot, ITTACA: a new database for integrated tumor transcriptome array and clinical data analysis, Nucleic Acids Res 34 (2006) D613-616.

[11] A. Kassambara, B. Klein, J. Moreaux, MMSET is overexpressed in cancers: link with tumor aggressiveness, Biochem Biophys Res Commun 379 (2009) 840-845.

[12] T. Reme, D. Hose, J. De Vos, A. Vassal, P.O. Poulain, V. Pantesco, H. Goldschmidt, B. Klein, A new method for class prediction based on signed-rank algorithms applied to Affymetrix microarray experiments, BMC Bioinformatics 9 (2008) 16. 
[13] J. Lee, S. Kotliarova, Y. Kotliarov, A. Li, Q. Su, N.M. Donin, S. Pastorino, B.W. Purow, N. Christopher, W. Zhang, J.K. Park, H.A. Fine, Tumor stem cells derived from glioblastomas cultured in bFGF and EGF more closely mirror the phenotype and genotype of primary tumors than do serum-cultured cell lines, Cancer Cell 9 (2006) 391-403.

[14] Y. Hao, G. Triadafilopoulos, P. Sahbaie, H.S. Young, M.B. Omary, A.W. Lowe, Gene expression profiling reveals stromal genes expressed in common between Barrett's esophagus and adenocarcinoma, Gastroenterology 131 (2006) 925-933.

[15] E.T. Kimchi, M.C. Posner, J.O. Park, T.E. Darga, M. Kocherginsky, T. Karrison, J. Hart, K.D. Smith, J.J. Mezhir, R.R. Weichselbaum, N.N. Khodarev, Progression of Barrett's metaplasia to adenocarcinoma is associated with the suppression of the transcriptional programs of epidermal differentiation, Cancer Res 65 (2005) 31463154.

[16] L. Badea, V. Herlea, S.O. Dima, T. Dumitrascu, I. Popescu, Combined gene expression analysis of whole-tissue and microdissected pancreatic ductal adenocarcinoma identifies genes specifically overexpressed in tumor epithelia, Hepatogastroenterology 55 (2008) 2016-2027.

[17] D. Segara, A.V. Biankin, J.G. Kench, C.C. Langusch, A.C. Dawson, D.A. Skalicky, D.C. Gotley, M.J. Coleman, R.L. Sutherland, S.M. Henshall, Expression of HOXB2, a retinoic acid signaling target in pancreatic cancer and pancreatic intraepithelial neoplasia, Clin Cancer Res 11 (2005) 3587-3596.

[18] C.A. lacobuzio-Donahue, A. Maitra, M. Olsen, A.W. Lowe, N.T. van Heek, C. Rosty, K. Walter, N. Sato, A. Parker, R. Ashfaq, E. Jaffee, B. Ryu, J. Jones, J.R. Eshleman, C.J. Yeo, J.L. Cameron, S.E. Kern, R.H. Hruban, P.O. Brown, M. Goggins, Exploration of global gene expression patterns in pancreatic adenocarcinoma using cDNA microarrays, Am J Pathol 162 (2003) 1151-1162.

[19] D. Singh, P.G. Febbo, K. Ross, D.G. Jackson, J. Manola, C. Ladd, P. Tamayo, A.A. Renshaw, A.V. D'Amico, J.P. Richie, E.S. Lander, M. Loda, P.W. Kantoff, T.R. Golub, W.R. Sellers, Gene expression correlates of clinical prostate cancer behavior, Cancer Cell 1 (2002) 203-209.

[20] J.B. Welsh, L.M. Sapinoso, A.I. Su, S.G. Kern, J. Wang-Rodriguez, C.A. Moskaluk, H.F. Frierson, Jr., G.M. Hampton, Analysis of gene expression identifies candidate markers and pharmacological targets in prostate cancer, Cancer Res 61 (2001) 5974-5978.

[21] D.K. Vanaja, J.C. Cheville, S.J. Iturria, C.Y. Young, Transcriptional silencing of zinc finger protein 185 identified by expression profiling is associated with prostate cancer progression, Cancer Res 63 (2003) 3877-3882.

[22] M.A. Ginos, G.P. Page, B.S. Michalowicz, K.J. Patel, S.E. Volker, S.E. Pambuccian, F.G. Ondrey, G.L. Adams, P.M. Gaffney, Identification of a gene expression signature associated with recurrent disease in squamous cell carcinoma of the head and neck, Cancer Res 64 (2004) 55-63.

[23] G.A. Toruner, C. Ulger, M. Alkan, A.T. Galante, J. Rinaggio, R. Wilk, B. Tian, P. Soteropoulos, M.R. Hameed, M.N. Schwalb, J.J. Dermody, Association between gene expression profile and tumor invasion in oral squamous cell carcinoma, Cancer Genet Cytogenet 154 (2004) 27-35. 
[24] H. Ye, T. Yu, S. Temam, B.L. Ziober, J. Wang, J.L. Schwartz, L. Mao, D.T. Wong, $X$. Zhou, Transcriptomic dissection of tongue squamous cell carcinoma, BMC Genomics 9 (2008) 69.

[25] R.S. Stearman, L. Dwyer-Nield, L. Zerbe, S.A. Blaine, Z. Chan, P.A. Bunn, Jr., G.L. Johnson, F.R. Hirsch, D.T. Merrick, W.A. Franklin, A.E. Baron, R.L. Keith, R.A. Nemenoff, A.M. Malkinson, M.W. Geraci, Analysis of orthologous gene expression between human pulmonary adenocarcinoma and a carcinogeninduced murine model, Am J Pathol 167 (2005) 1763-1775.

[26] L.J. Su, C.W. Chang, Y.C. Wu, K.C. Chen, C.J. Lin, S.C. Liang, C.H. Lin, J. WhangPeng, S.L. Hsu, C.H. Chen, C.Y. Huang, Selection of DDX5 as a novel internal control for Q-RT-PCR from microarray data using a block bootstrap re-sampling scheme, BMC Genomics 8 (2007) 140.

[27] S. Wachi, K. Yoneda, R. Wu, Interactome-transcriptome analysis reveals the high centrality of genes differentially expressed in lung cancer tissues, Bioinformatics 21 (2005) 4205-4208.

[28] M.E. Garber, O.G. Troyanskaya, K. Schluens, S. Petersen, Z. Thaesler, M. PacynaGengelbach, M. van de Rijn, G.D. Rosen, C.M. Perou, R.I. Whyte, R.B. Altman, P.O. Brown, D. Botstein, I. Petersen, Diversity of gene expression in adenocarcinoma of the lung, Proc Natl Acad Sci U S A 98 (2001) 13784-13789.

[29] J. Hou, J. Aerts, B. den Hamer, W. van ljcken, M. den Bakker, P. Riegman, C. van der Leest, P. van der Spek, J.A. Foekens, H.C. Hoogsteden, F. Grosveld, S.

Philipsen, Gene expression-based classification of non-small cell lung carcinomas and survival prediction, PLoS One 5 (2010) e10312.

[30] M.T. Landi, T. Dracheva, M. Rotunno, J.D. Figueroa, H. Liu, A. Dasgupta, F.E. Mann, J. Fukuoka, M. Hames, A.W. Bergen, S.E. Murphy, P. Yang, A.C. Pesatori, D. Consonni, P.A. Bertazzi, S. Wacholder, J.H. Shih, N.E. Caporaso, J. Jen, Gene expression signature of cigarette smoking and its role in lung adenocarcinoma development and survival, PLoS One 3 (2008) e1651.

[31] K. Basso, A.A. Margolin, G. Stolovitzky, U. Klein, R. Dalla-Favera, A. Califano, Reverse engineering of regulatory networks in human B cells, Nat Genet 37 (2005) 382-390.

[32] A. Andersson, C. Ritz, D. Lindgren, P. Eden, C. Lassen, J. Heldrup, T. Olofsson, J. Rade, M. Fontes, A. Porwit-Macdonald, M. Behrendtz, M. Hoglund, B. Johansson, T. Fioretos, Microarray-based classification of a consecutive series of 121 childhood acute leukemias: prediction of leukemic and genetic subtype as well as of minimal residual disease status, Leukemia 21 (2007) 1198-1203.

[33] J. Durig, S. Bug, L. Klein-Hitpass, T. Boes, T. Jons, J.I. Martin-Subero, L. Harder, M. Baudis, U. Duhrsen, R. Siebert, Combined single nucleotide polymorphismbased genomic mapping and global gene expression profiling identifies novel chromosomal imbalances, mechanisms and candidate genes important in the pathogenesis of T-cell prolymphocytic leukemia with inv(14)(q11q32), Leukemia 21 (2007) 2153-2163.

[34] T.G. Grunewald, I. Diebold, I. Esposito, S. Plehm, K. Hauer, U. Thiel, P. da SilvaButtkus, F. Neff, R. Unland, C. Muller-Tidow, C. Zobywalski, K. Lohrig, U. Lewandrowski, A. Sickmann, O.P. da Costa, A. Gorlach, A. Cossarizza, E. Butt, G.H. Richter, S. Burdach, STEAP1 Is Associated with the Invasive and Oxidative Stress Phenotype of Ewing Tumors, Mol Cancer Res 10 (2012) 52-65. 
[35] A. Kassambara, D. Hose, J. Moreaux, B.A. Walker, A. Protopopov, T. Reme, F. Pellestor, V. Pantesco, A. Jauch, G. Morgan, H. Goldschmidt, B. Klein, Genes with a spike expression are clustered in chromosome (sub)bands and spike (sub)bands have a powerful prognostic value in patients with multiple myeloma, Haematologica (2011).

[36] F. Zhan, Y. Huang, S. Colla, J.P. Stewart, I. Hanamura, S. Gupta, J. Epstein, S. Yaccoby, J. Sawyer, B. Burington, E. Anaissie, K. Hollmig, M. Pineda-Roman, G. Tricot, F. van Rhee, R. Walker, M. Zangari, J. Crowley, B. Barlogie, J.D. Shaughnessy, Jr., The molecular classification of multiple myeloma, Blood 108 (2006) 2020-2028.

[37] C.A. Boswell, E.E. Mundo, C. Zhang, D. Bumbaca, N.R. Valle, K.R. Kozak, A. Fourie, J. Chuh, N. Koppada, O. Saad, H. Gill, B.Q. Shen, B. Rubinfeld, J. Tibbitts, S. Kaur, F.P. Theil, P.J. Fielder, L.A. Khawli, K. Lin, Impact of drug conjugation on pharmacokinetics and tissue distribution of anti-STEAP1 antibodydrug conjugates in rats, Bioconjug Chem 22 (2011) 1994-2004.

[38] Y.Z. Pan, Y. Li, L.R. Guo, Y.Y. Zhao, X.J. Zhao, [Influence of expression of six transmembrane epithelial antigen of the prostate-1 on intracellular reactive oxygen species level and cell growth: an in vitro experiment], Zhonghua Yi Xue Za Zhi 88 (2008) 641-644.

[39] J. Luo, N.L. Solimini, S.J. Elledge, Principles of cancer therapy: oncogene and nononcogene addiction, Cell 136 (2009) 823-837.

[40] T.P. Szatrowski, C.F. Nathan, Production of large amounts of hydrogen peroxide by human tumor cells, Cancer Res 51 (1991) 794-798. 


\section{Figure legends}

Figure 1: Increased STEAP1 gene expression in cancer tissue compared to normal counterparts.

STEAP1 gene expression in glioblastoma, esophageal adenocarcinoma, pancreatic carcinoma, prostate cancer, head and neck cancer, lung adenocarcinoma, primary effusion lymphoma, T-cell acute lymphoblastic leukemia, acute myeloid leukemia, B-cell acute lymphoblastic leukemia, T-cell prolymphocytic leukemia and the corresponding normal tissues Data sets in a given panel were from the same study. GEP data are log transformed and normalized as previously described[8].

Figure 2: Overall survival related to STEAP1 gene expression in cancers The prognostic value of STEAP1 gene expression was determined using the MaxStat $R$ function in R software. The overall survival of subgroups of patients was compared with the log-rank test and survival curves computed with the Kaplan-Meier method ( $R$ software).

Figure 3: STEAP1 expression in the 7 molecular groups of malignant plasma cells documented in patients with previously-untreated multiple myeloma.

The expression of STEAP1 gene was investigated in the 7 molecular groups of UAMS cohort of patients treated with Total therapy 2 protocol. PR: proliferation, LB: low bone disease, MS: MMSET, HY: hyperdiploid, CD1: Cyclin D1, D2: Cyclin D2, MF: MAF. * indicates a $P$ value $<.05$ and ${ }^{* *}$ indicates a $P$ value $<.01$ 
Figure 4: Validation of STEAP1 expression. (A) Expression level of STEAP1 protein in HMCLs using Western blot and correlation with STEAP1 gene expression Affymetrix signal value. For each cell line, the ratios of STEAP1 and $\beta$-actin proteins were determined in order to compare STEAP1 protein expression between cell lines. (B) STEAP1 protein expression in purified primary myeloma cells using Western blot analysis. (C) STEAP1 protein expression in STEAP1 negative XG-12 and STEAP1 positive LP1 HMCLs using immunofluorescence analysis. 


\begin{tabular}{|c|c|c|}
\hline & & $\begin{array}{c}\text { Gene overexpression compared to normal tissue } \\
\text { counterpart }\end{array}$ \\
\hline Tissue & Datasets & Steap1 \\
\hline Myeloma & 28 & No \\
\hline Leukemia & 79 & Yes \\
\hline Lymphoma & 48 & Yes \\
\hline Bladder & 17 & No \\
\hline Brain & 55 & Yes \\
\hline Breast & 116 & No \\
\hline Cervical & 13 & No \\
\hline Colorectal & 69 & No \\
\hline Kidney & 32 & No \\
\hline Esophageal & 17 & Yes \\
\hline Gastric & 17 & No \\
\hline Head \& Neck & 27 & Yes \\
\hline Liver & 22 & No \\
\hline Lung & 64 & Yes \\
\hline Melanoma & 44 & No \\
\hline Ovarian & 37 & No \\
\hline Pancreas & 24 & Yes \\
\hline Prostate & 52 & Yes \\
\hline Sarcoma & 40 & No \\
\hline
\end{tabular}

Table 1:

Expression of STEAP1 gene in human tumors and in normal tissue

counterparts using publicly available gene expression data, including the Oncomine Cancer Microarray database. 
$P=.02$

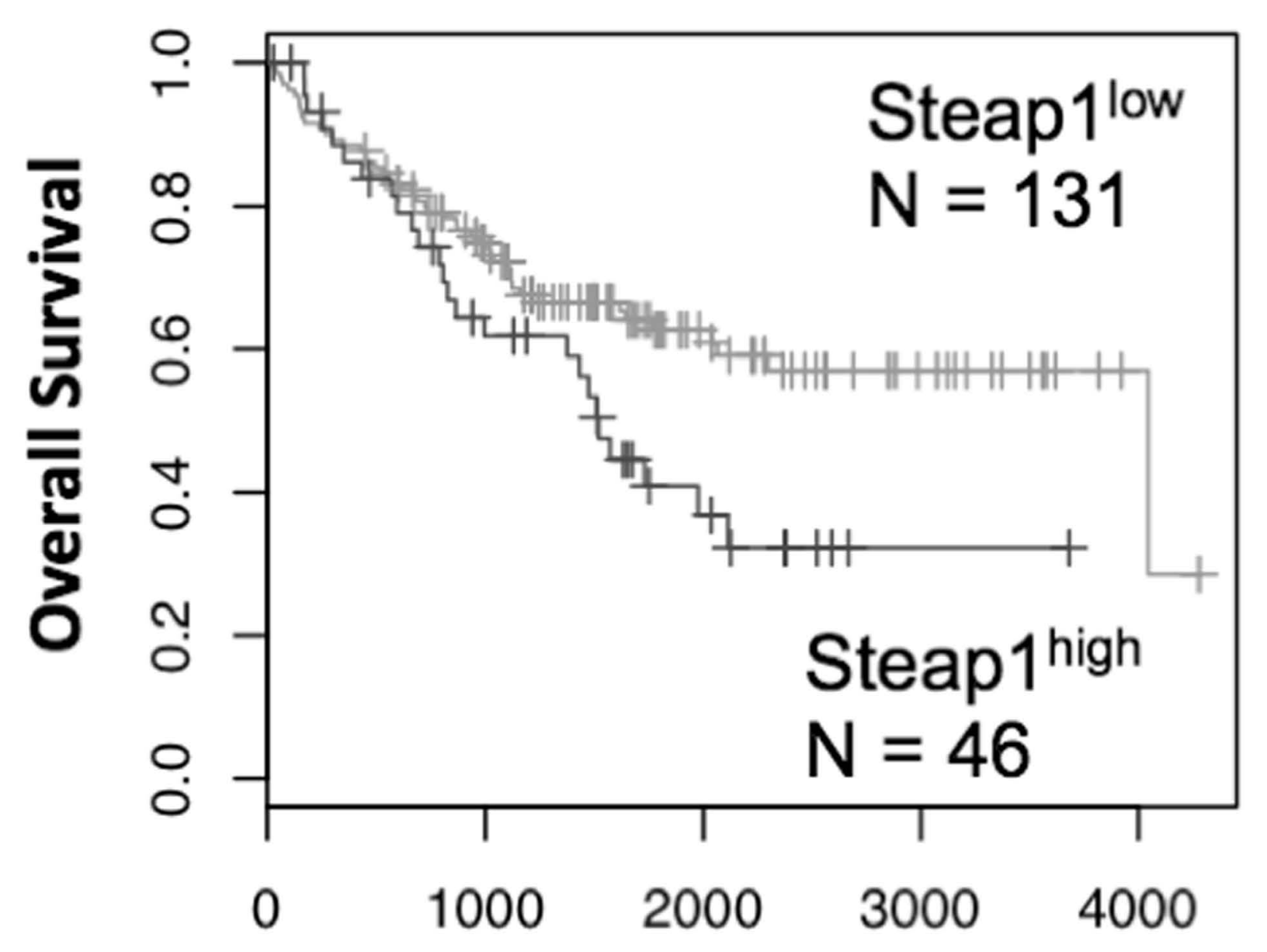

Days from diagnosis

Multiple Myeloma N=206

$$
P=.01
$$

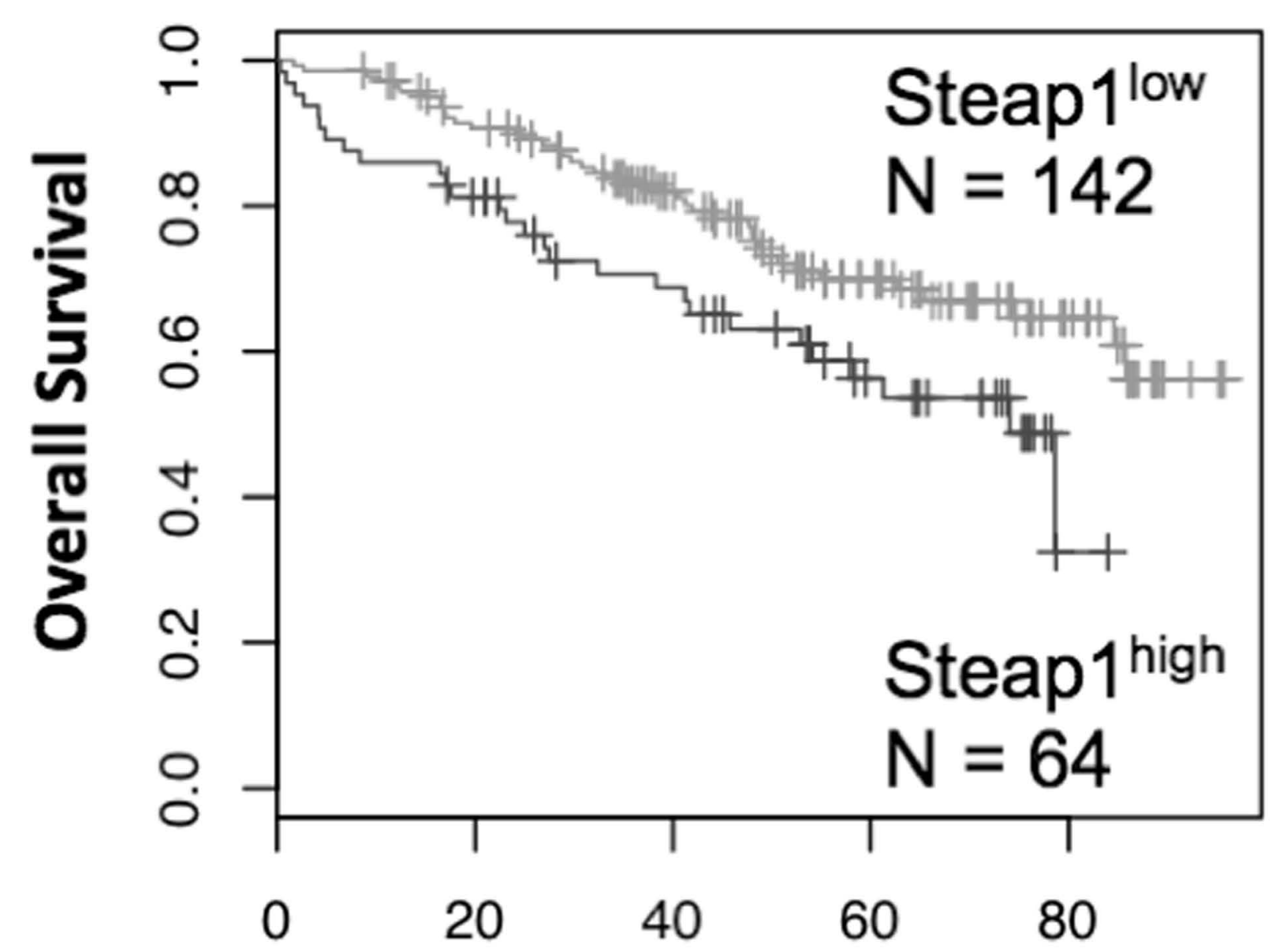

Months from diagnosis
$P=.008$

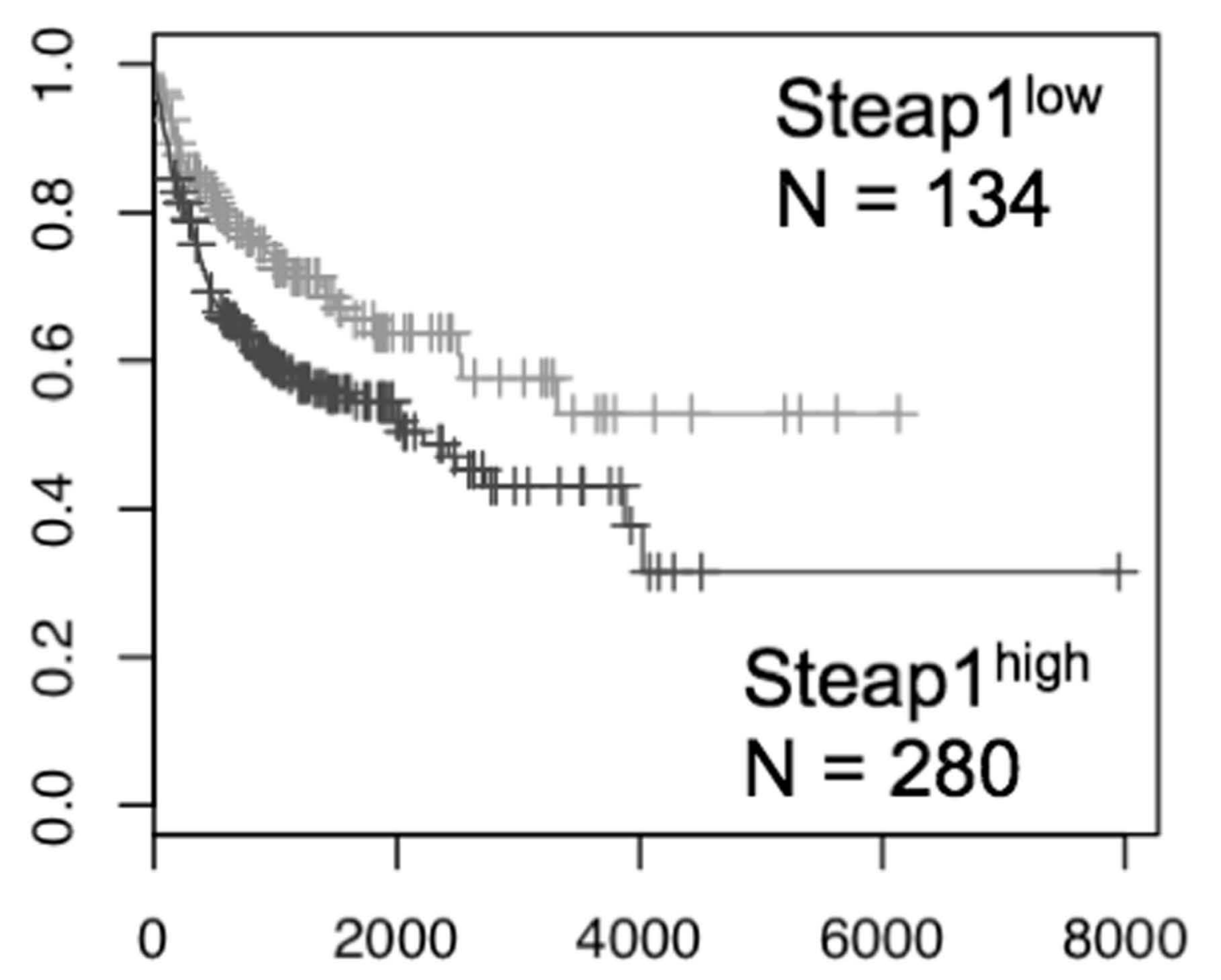

Days from diagnosis

Multiple Myeloma N=345

$$
P=.02
$$

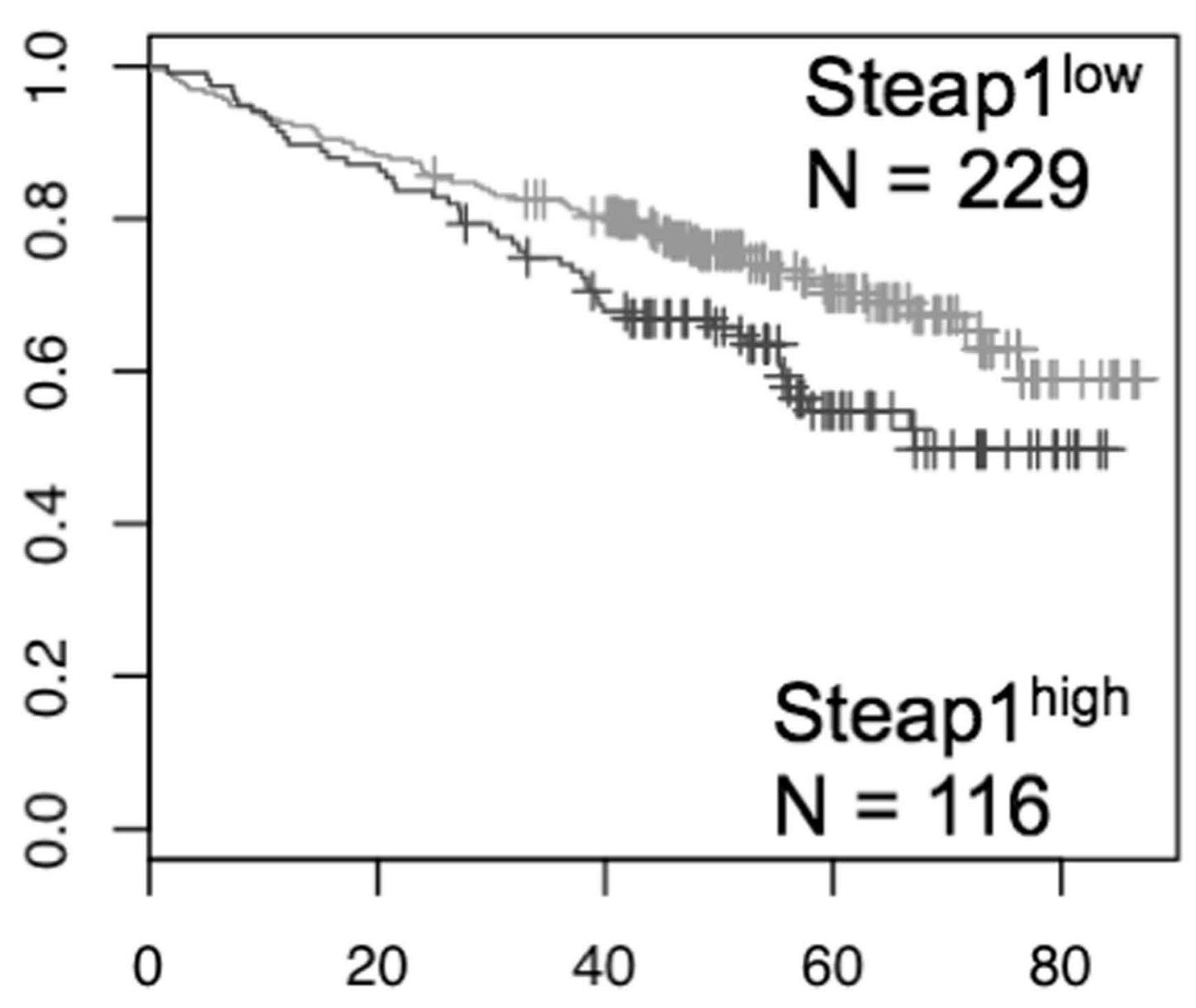

Months from diagnosis
$P=.0005$

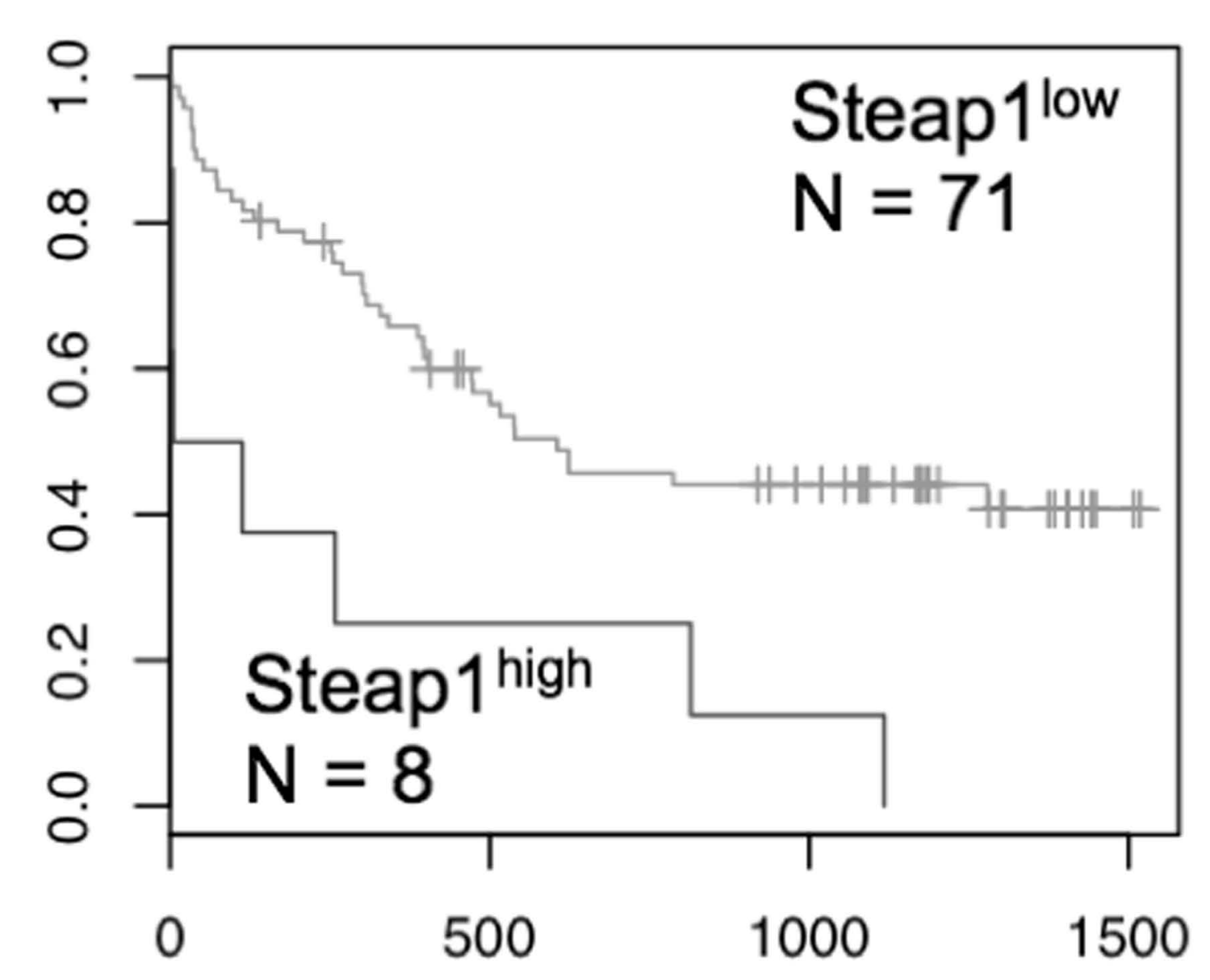

Days from diagnosis

\section{Low Steap1 expression}

High Steap1 expression

\section{Figure 2}


Figure 3

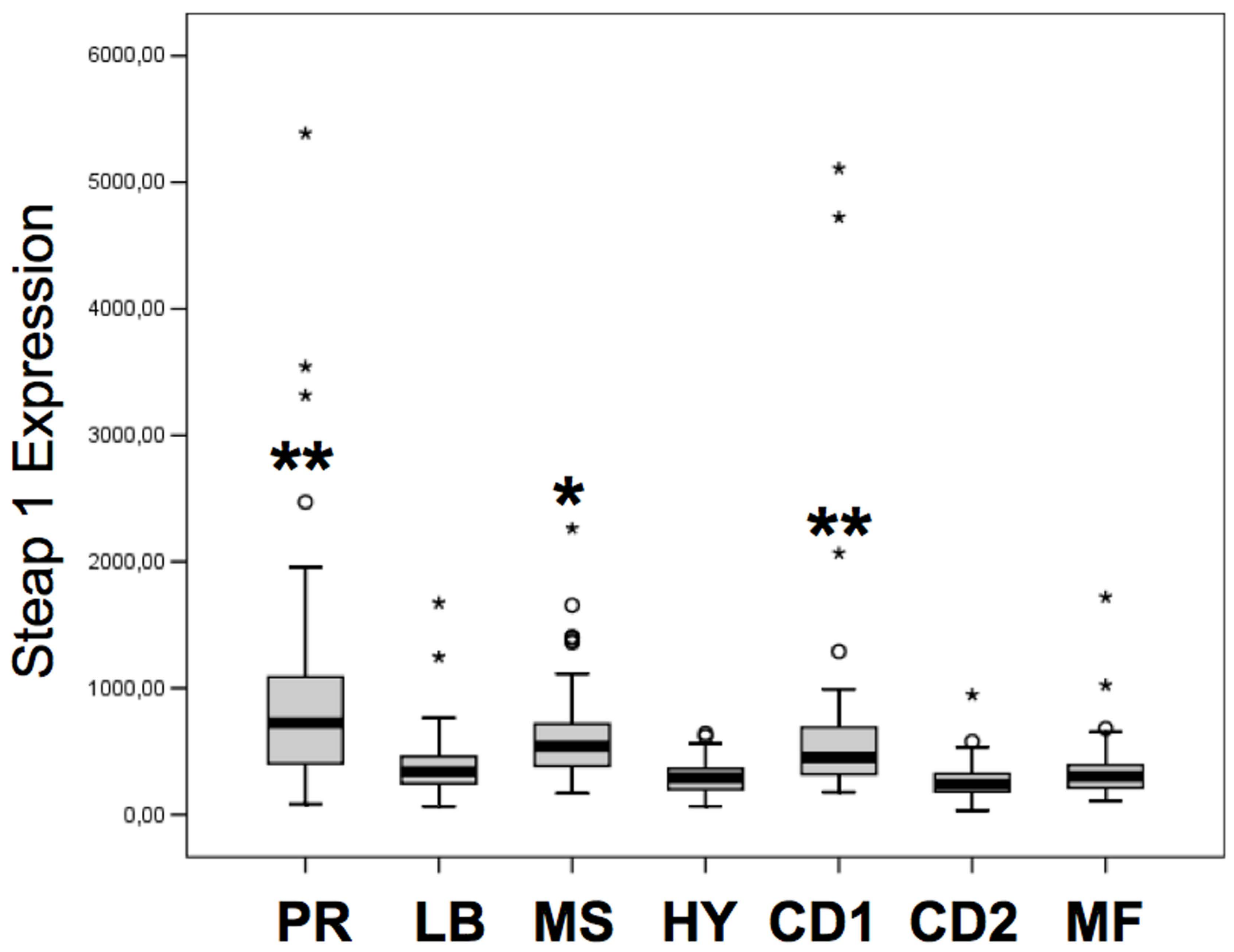


XG-7 U266 XG12 XG10 LP1

$40 \mathrm{kD}$

Steap1

$43 \mathrm{kD}$
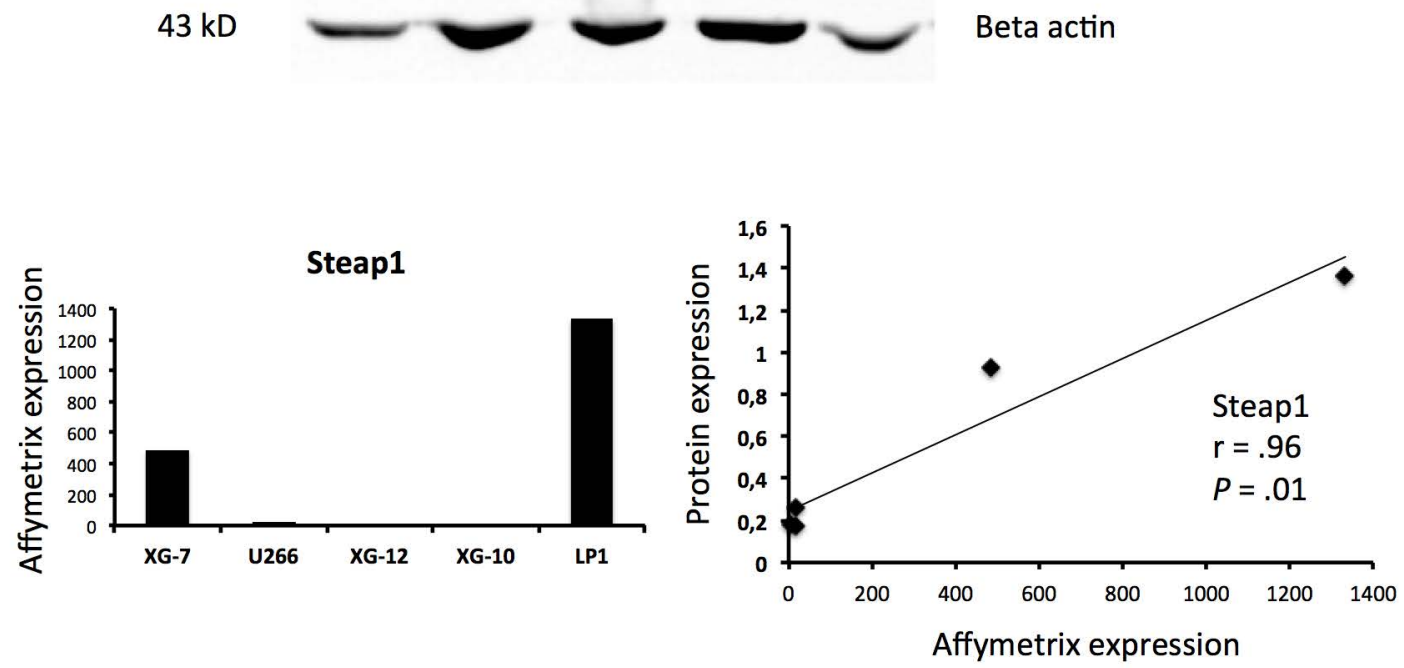

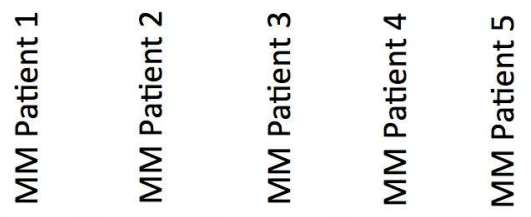

Figure 4B

$40 \mathrm{kD}$

Steap1

$43 \mathrm{kD}$

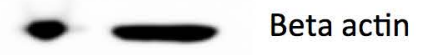

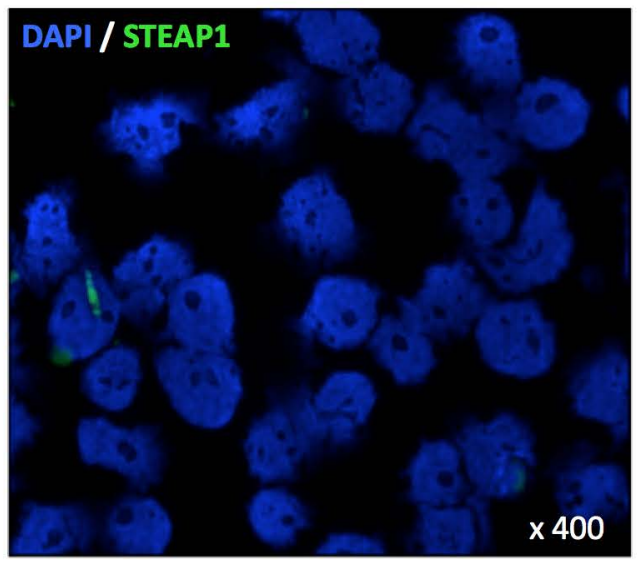

XG-12



LP1 

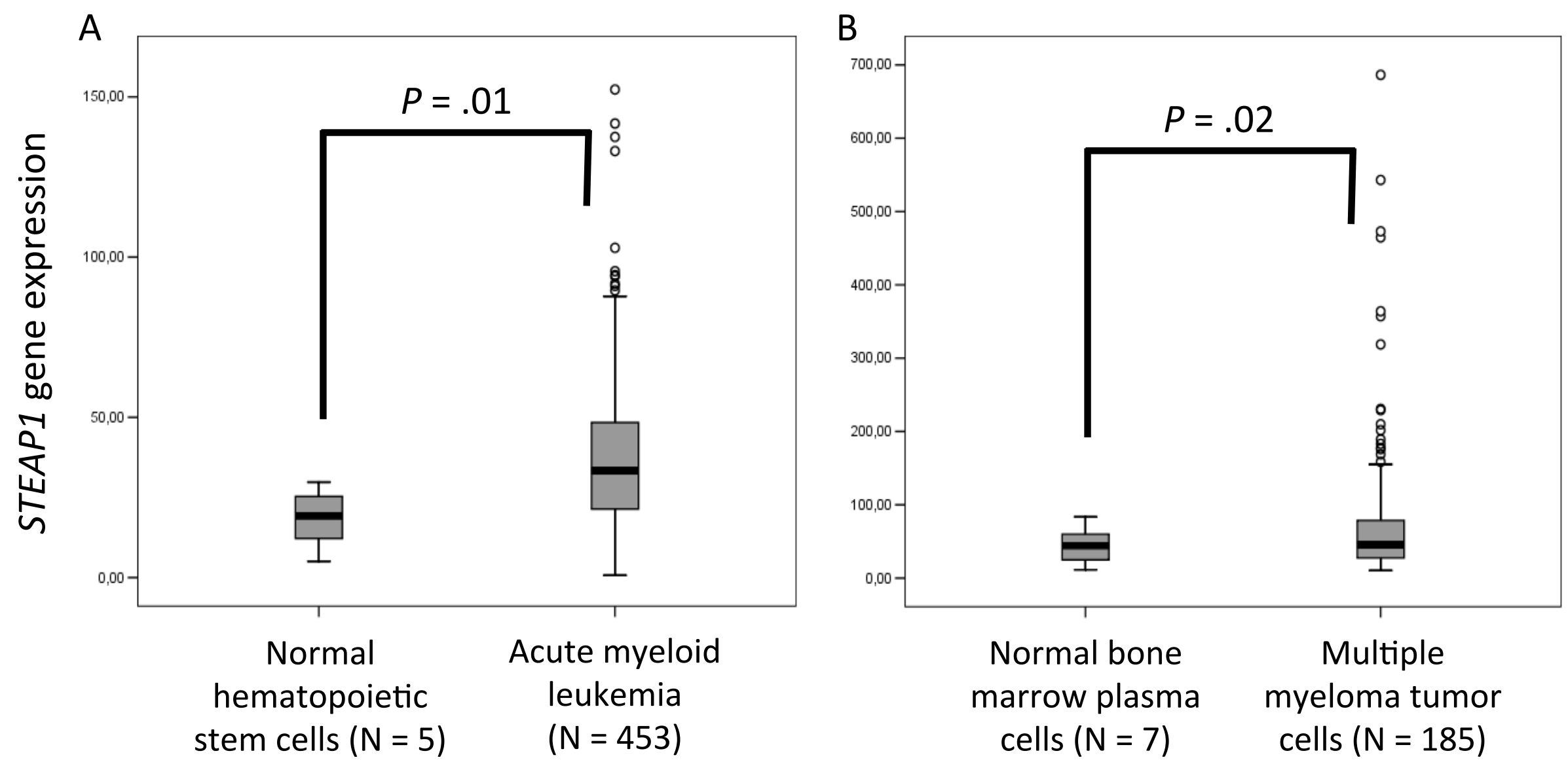

Supplementary Figure S1: STEAP1 expression in (A) AML tumor cells compared to normal hematopoietic stem cells and (B) in MM tumor cells compared to normal bone marrow plasma cells (Amazonia database (http:// amazonia.montp.inserm.fr/). 


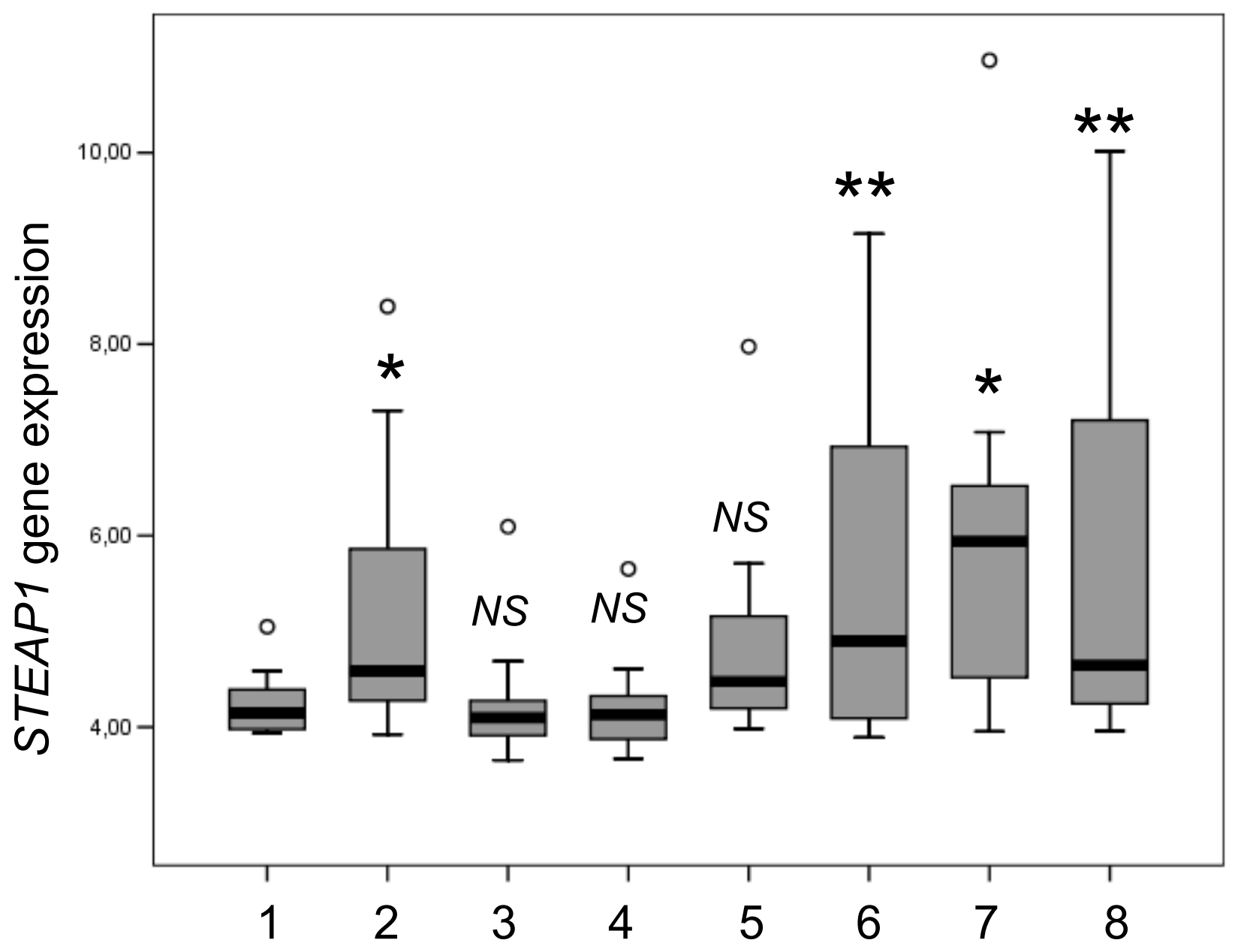

1 - Prostate carcinoma cell lines $(\mathrm{N}=7)$

2 - Acute lymphoblastic $T$ cell leukemia cell lines $(N=13)$

3 - Acute myeloid leukemia cell lines $(\mathrm{N}=33)$

4 - Acute lymphoblastic $B$ cell leukemia cell lines $(N=12)$

5 - Burkitt lymphoma cell lines $(\mathrm{N}=10)$

6 - Diffuse large $B$ cell lymphoma cell lines $(N=16)$

7 - Hodgkin lymphoma cell lines $(\mathrm{N}=13)$

8 - Multiple myeloma cell lines $(\mathrm{N}=27)$ 


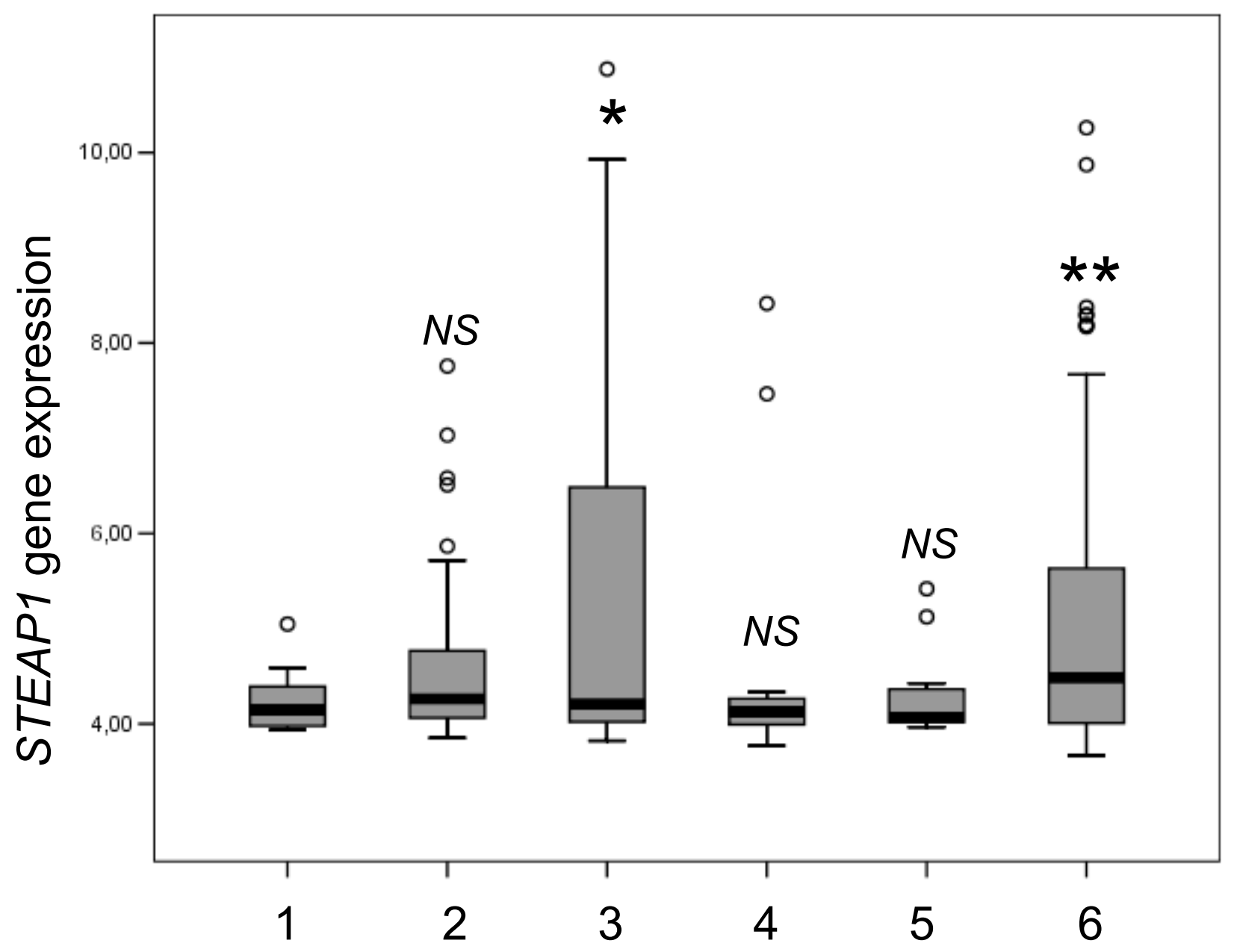

B

1 - Prostate carcinoma cell lines $(\mathrm{N}=7)$

2 - Glioma cell lines $(N=27)$

3 - Oesophagus carcinoma cell lines $(\mathrm{N}=23)$

4 - Pancreas carcinoma cell lines $(\mathrm{N}=18)$

5 - Pancreatic ductal carcinoma cell lines $(N=13)$

6 - Lung carcinoma cell lines $(N=78)$ 
Supplementary Figure S2: STEAP1 gene expression in (A) acute lymphoblastic $T$ cell leukemia, diffuse large $B$ cell lymphoma, Hodgkin lymphoma, multiple myeloma, acute myeloid leukemia, acute lymphoblastic B cell leukemia, Burkitt lymphoma, (B) oesophagus carcinoma and lung carcinoma cell lines, glioma, pancreas carcinoma and pancreatic ductal carcinoma cell lines compared to prostate cancer cell lines. 